Review Article

\title{
Stomatitis and VEGFR-Tyrosine Kinase Inhibitors (VR-TKIs): A Review of Current Literature in 4369 Patients
}

\author{
Claudia Arena $(\mathbb{D}$, Giuseppe Troiano $\mathbb{D}$, Alfredo De Lillo, \\ Nunzio F. Testa, and Lorenzo Lo Muzio $(D)$ \\ Department of Clinical and Experimental Medicine, University of Foggia, Foggia, Italy \\ Correspondence should be addressed to Lorenzo Lo Muzio; lorenzo.lomuzio@unifg.it
}

Received 21 January 2018; Revised 25 February 2018; Accepted 5 March 2018; Published 24 May 2018

Academic Editor: Stefano Fedele

Copyright (C) 2018 Claudia Arena et al. This is an open access article distributed under the Creative Commons Attribution License, which permits unrestricted use, distribution, and reproduction in any medium, provided the original work is properly cited.

Background. Multitargeted tyrosine kinase inhibitors (TKIs) represent a new class of target-specific antineoplastic agents. These agents show some specific adverse events such as fatigue/asthenia, anorexia/loss of appetite, dysgeusia, diarrhea/abdominal pain, hypothyroidism, hypertension, myelosuppression, and stomatitis. Materials and Methods. A systematic search was performed on PubMed online database using a combination of MESH terms and free text words, "sunitinib" OR "sorafenib" OR "axitinib" OR "cabozantinib" OR "pazopanib" OR "regorafenib" OR "nintedanib" OR "vatalanib" combined through the use of Boolean operator AND with the key words "stomatitis" OR "mucositis," (i) on human subjects, (ii) written in the English language, and (iii) reporting about the incidence of stomatitis or oral mucositis. Results. The incidence of stomatitis of any grade was $35.2 \%$ for sunitinib, $20.52 \%$ for sorafenib, $20.63 \%$ for axitinib, and $34.21 \%$ for cabozantinib. All the agents showed high rates of lowgrade stomatitis (G1-G2), while the onset of severe stomatitis (G3-G4) was very low. Conclusions. Analysis of the reports with patients treated with sunitinib, sorafenib, axitinib, and cabozantinib showed a clear prevalence of stomatitis grade 1 or grade 2 . These data differ from those of patients treated with conventional chemotherapy in which mucositis is predominantly of grade 3 or grade 4 .

\section{Introduction}

Traditional treatment of malignancies with chemotherapeutic agents often causes the damage of normal healthy cells [1]. Toxicities of the oral cavity, such as mucositis and stomatitis, are some of the most significant and unavoidable side effects associated with cancer treatment [2]. Oral toxicities have a huge impact on the patient with cancer and are a common cause of dose delays and interruptions of cancer therapy [3]. The terms "oral mucositis" and "stomatitis" are often used interchangeably to indicate oral complications of anticancer therapy, but they do not refer to the same process (Parkhill, 2013). Oral mucositis is a Medical Subject Headings term that describes inflammation of oral mucosa due to chemotherapeutic agents or ionizing radiation. Stomatitis is a less specific term used to describe any inflammatory condition of oral tissue. For such reason in the last decades, newer targeted agents have been developed, aiming to decrease the rates of side effects on healthy cells.
Multitargeted tyrosine kinase inhibitors (TKIs) represent a novel class of target-specific antineoplastic agents. The mechanism of action of this class of drugs is based on the block of several key tyrosine kinase pathways in human cancers, including the vascular endothelial growth factor receptor (VEGFR), epidermal growth factor receptor (EGFR), human epidermal growth factor receptor 2 (HER2), and platelet-derived growth factor receptor (PDGFR) [46]. Molecules that inhibit VEGFR-Tyrosine Kinase Inhibitors (VR-TKIs) are an emerging class of highly effective targeted therapies due to their demonstrated efficacy in a variety of malignancies [5, 7-12]. FDA-approved VR-TKIs include sorafenib (renal cell carcinoma [RCC], hepatocellular carcinoma $[\mathrm{HCC}]$, and thyroid cancer), sunitinib (RCC, HCC, and gastrointestinal stromal tumor [GIST]), pazopanib (RCC and soft tissue sarcomas), cabozantinib (metastatic medullary thyroid cancer), and regorafenib (GIST and colorectal carcinoma [CRC]) $[9,10,13-17]$. 


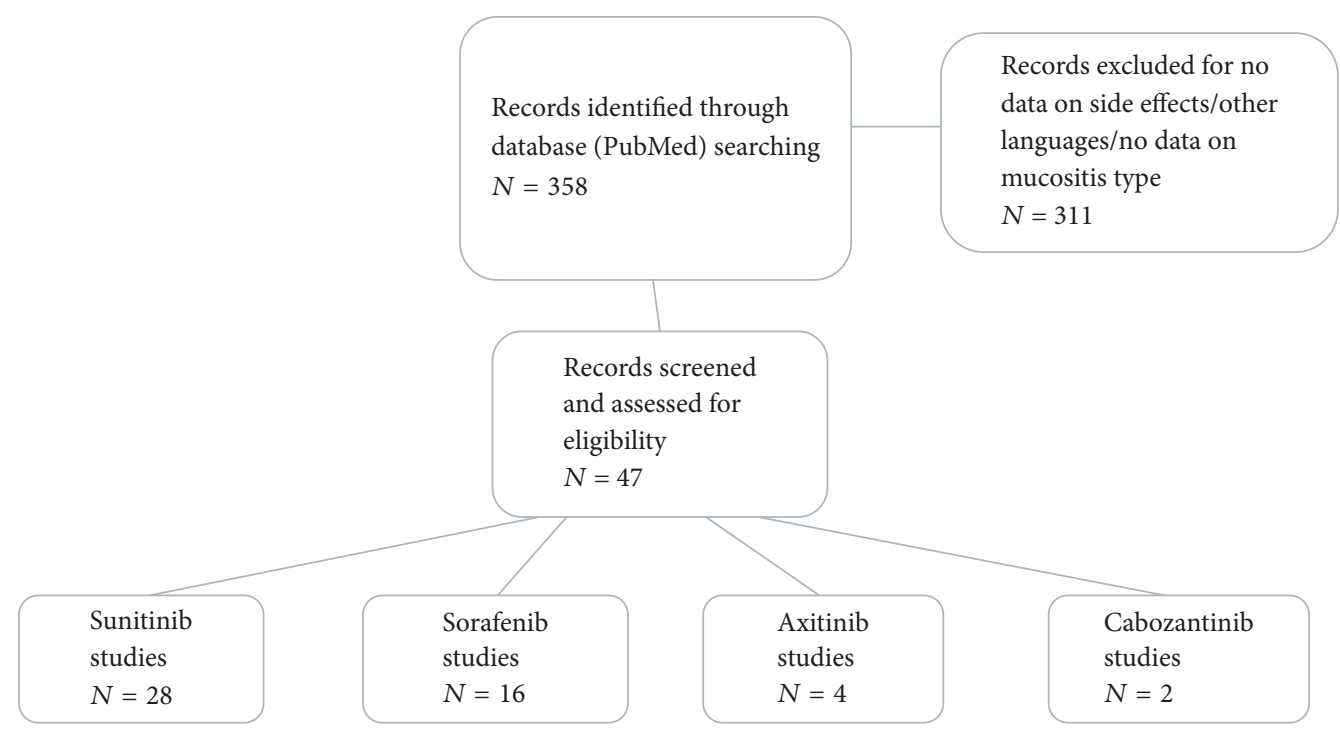

FIGURE 1: Flow chart showing the process of papers selection used in this review.

Even this kind of targeted therapy based on VR-TKIs showed some class-specific adverse events that include fatigue/asthenia, anorexia/loss of appetite, hand-foot skin reaction, stomatitis, dysgeusia, diarrhea/abdominal pain, hypothyroidism, hypertension, and myelosuppression [6366]. Literature reported that $25 \%$ of patients treated with multitargeted angiogenesis kinase inhibitors develop an oral adverse event within 2 months of therapy [67].

\section{Materials and Methods}

The following review was performed to answer to the following question: "which is the rate of incidence of oral stomatitis in patients treated with VEGF TKIs?"

A systematic search was performed on the PubMed online database using a combination of MESH terms and free text words, "sunitinib" (free text) OR "sorafenib" (free text) OR "axitinib" (free text) OR "cabozantinib" (free text) OR "pazopanib" (free text) OR "regorafenib" (free text) OR "nintedanib" (free text) OR "vatalanib" (free text) combined through the use of Boolean operator AND with the key words "stomatitis" (MESH) OR "mucositis" (MESH), (i) performed on human subjects, (ii) reporting about the use of an mTOR inhibitor, (iii) written in the English language, and (iv) reporting about the incidence of stomatitis or oral mucositis.

Case reports and studies on animal model were excluded from this study. No restrictions were applied to the year of publication.

For each study, the following records were extracted: name of the first author, year of publication, number of patients enrolled, type of disease treated, number of events recorded, and grade of the events reported. To simplify the process of data extraction, an ad hoc extraction sheet was used. In addition, data were independently extracted by two authors (Lorenzo Lo Muzio and Claudia Arena) and checked in a joint session.

\section{Results}

3.1. Bibliographic Research. Titles and abstract of 358 potentially relevant studies were screened; of these, 311 studies were excluded because they did not meet the inclusion criteria (Figure 1). The full texts of 47 studies were read. Of the included studies, 28 referred to sunitinib use, 16 to sorafenib, 4 to axitinib, and 2 to cabozantinib. Of these, 5 referred to both sunitinib and sorafenib and 2 referred to both axitinib and sorafenib.

3.2. Analysis of Data. For sunitinib, 28 studies were analyzed (Table 1). A total of 2.596 patients were treated with sunitinib. The overall incidence of stomatitis of any grade with treatment was 35.2\% (914 patients). Studies reported data about grade of stomatitis for 2068 patients and 739 cases were grade $1 / 2(35.73 \%)$ and 90 were grade $3 / 4(5.35 \%)$.

For sorafenib, 16 studies were analyzed (Table 2). A total of 1218 patients were treated with sorafenib. The overall incidence of stomatitis of any grade with treatment was $20.52 \%$ (250 patients). Studies reported data about grade of stomatitis for 830 patients and 174 cases were grade $1 / 2$ (20.96\%) and 19 were grade $3 / 4$ (2.28\%).

For axitinib, 4 studies were analyzed (Table 3 ). A total of 441 patients were treated with axitinib. The overall incidence of stomatitis of any grade with axitinib treatment was $20.63 \%$ (91 patients) and 79 cases were grade 1/2 (17.91\%) and 12 were grade $3 / 4(2.72 \%)$.

For cabozantinib, 2 studies were analyzed (Table 4). A total of 114 patients were treated with cabozantinib. The overall incidence of stomatitis of any grade with cabozantinib treatment was $34.21 \%$ (39 patients) and 34 cases were grade $1 / 2(29.82 \%)$ and 5 were grade $3 / 4(4.38 \%)$.

\section{Discussion}

Targeted therapy is a kind of chemotherapy that inhibits a molecular target which is abnormally expressed in malignancy. 


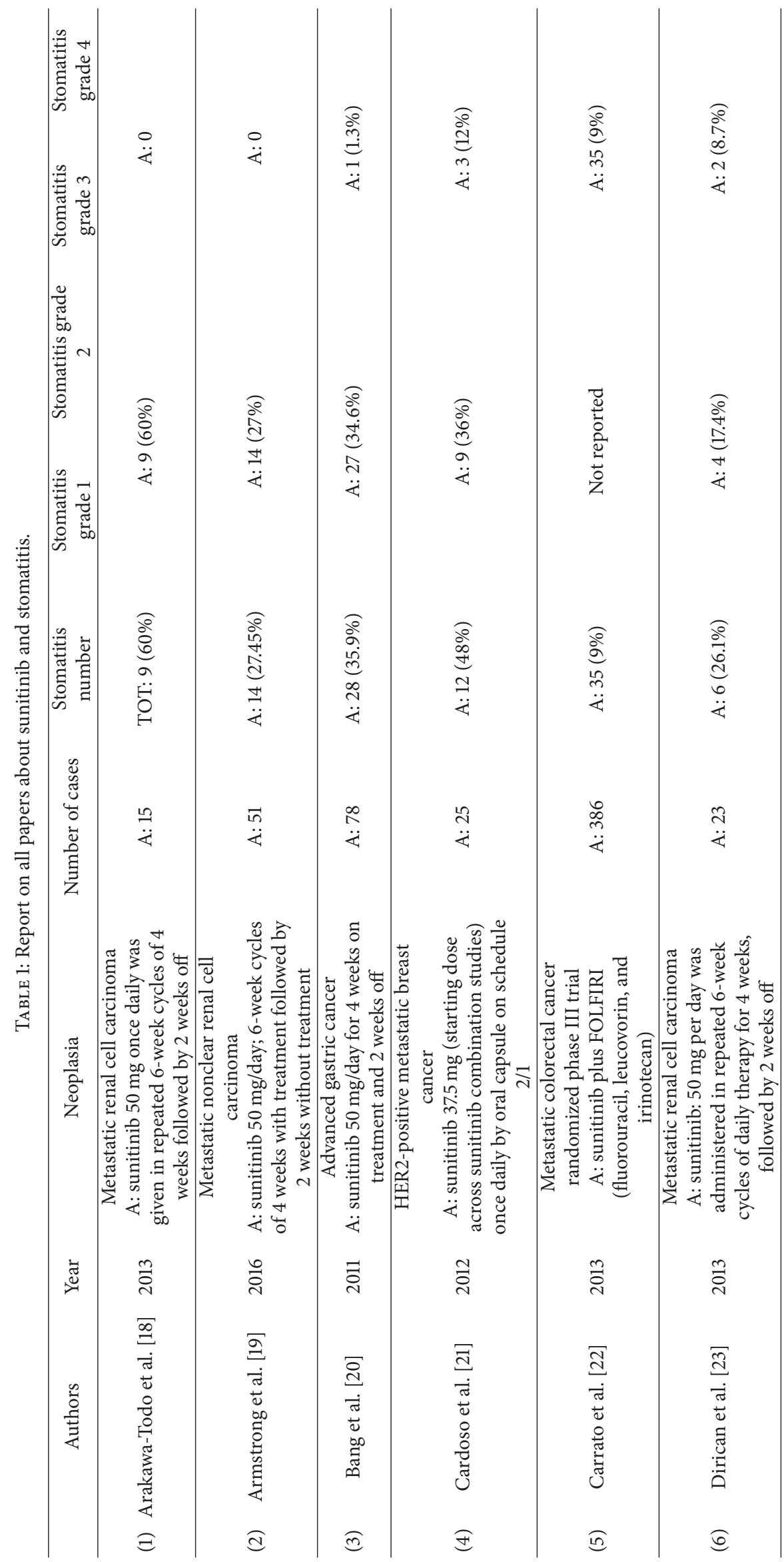




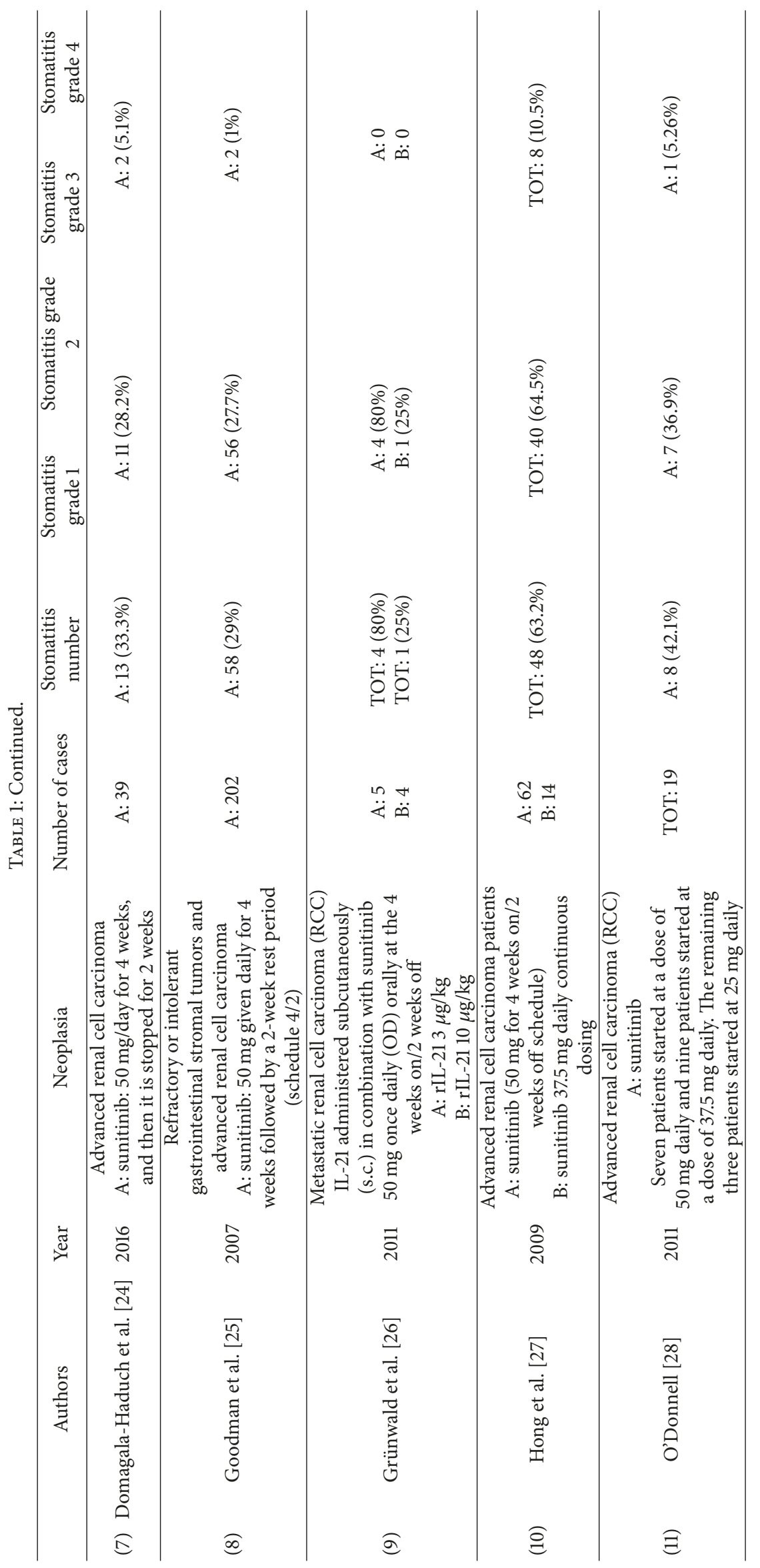




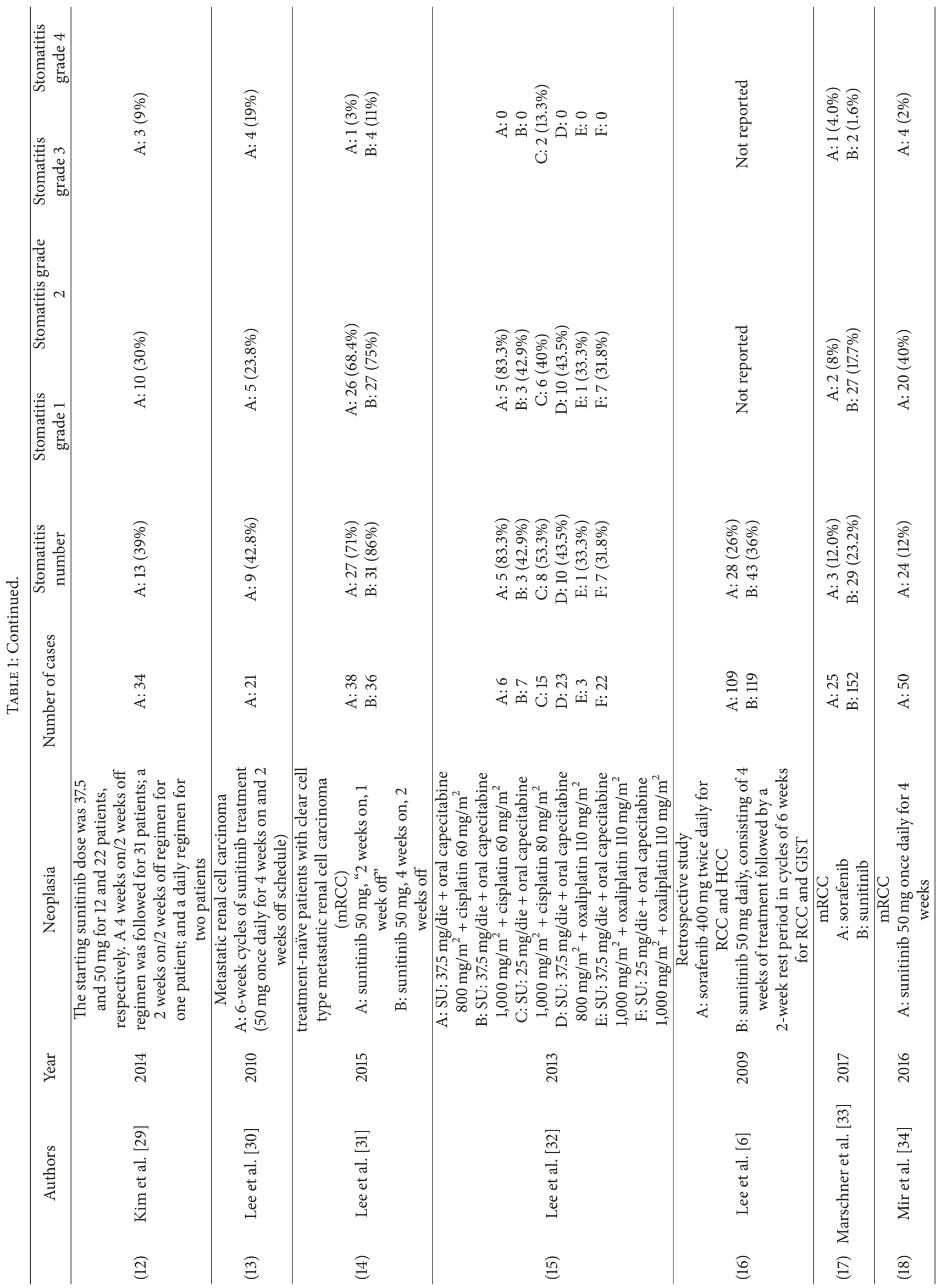




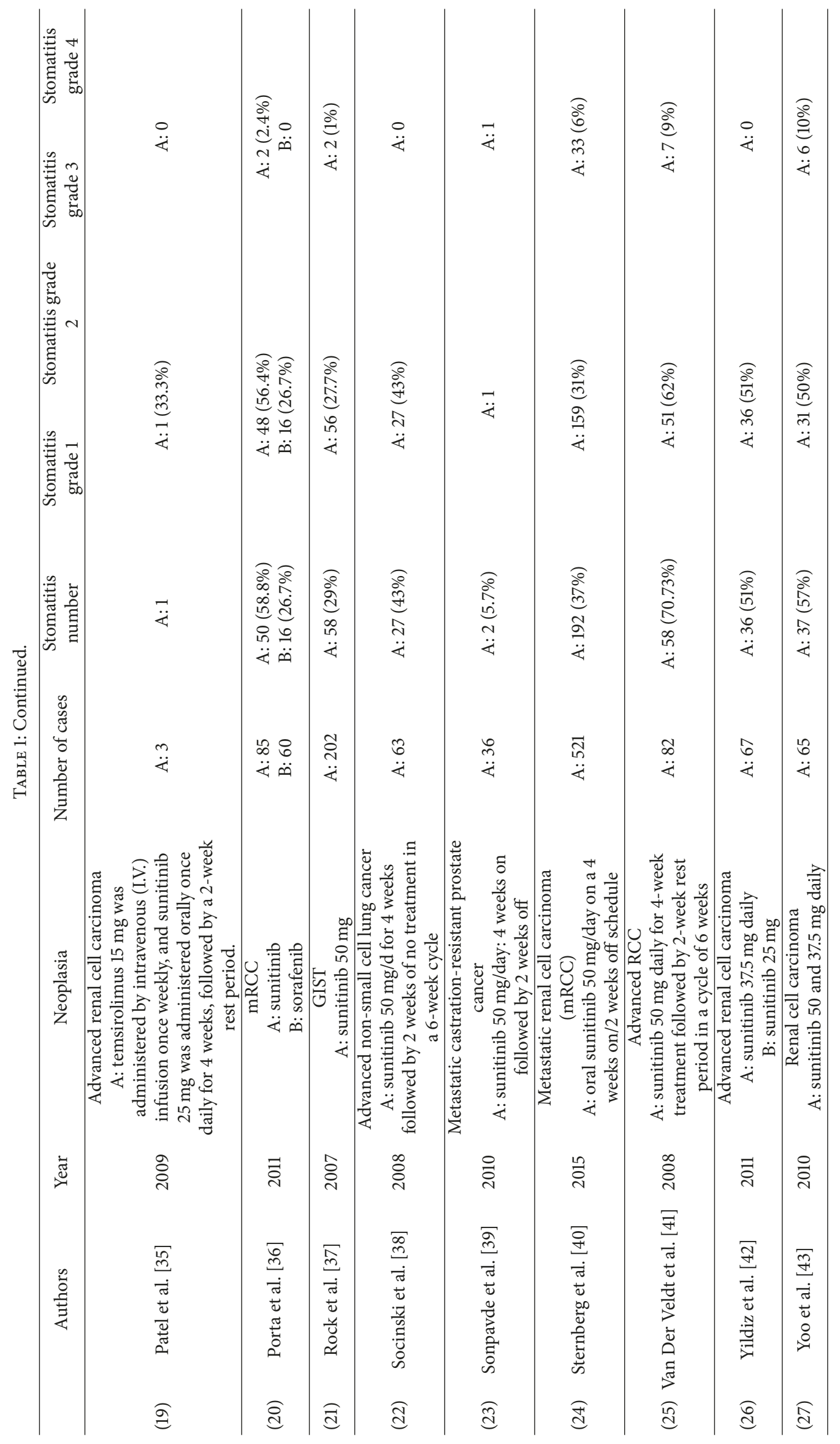




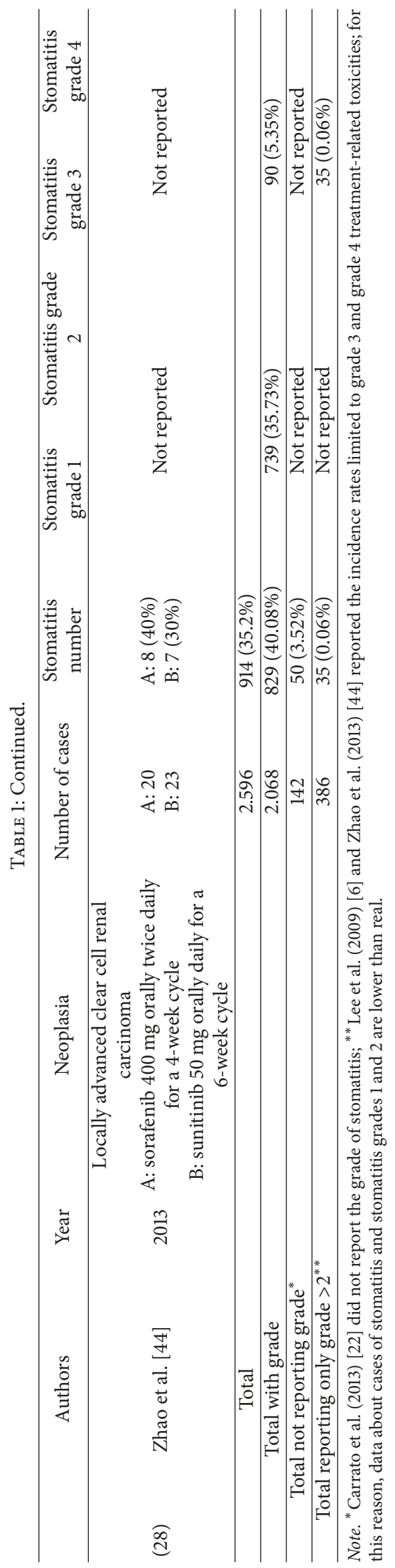




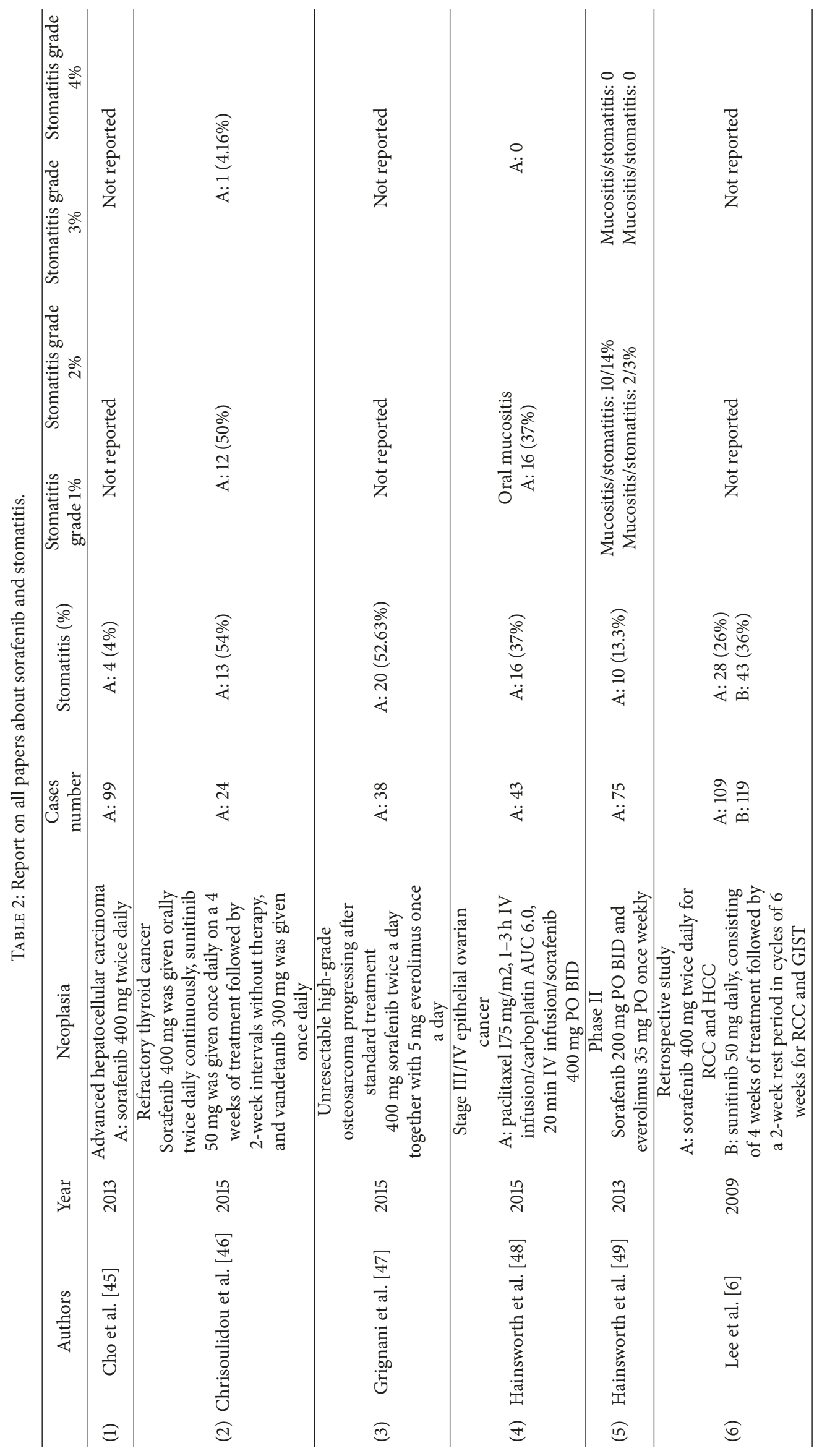




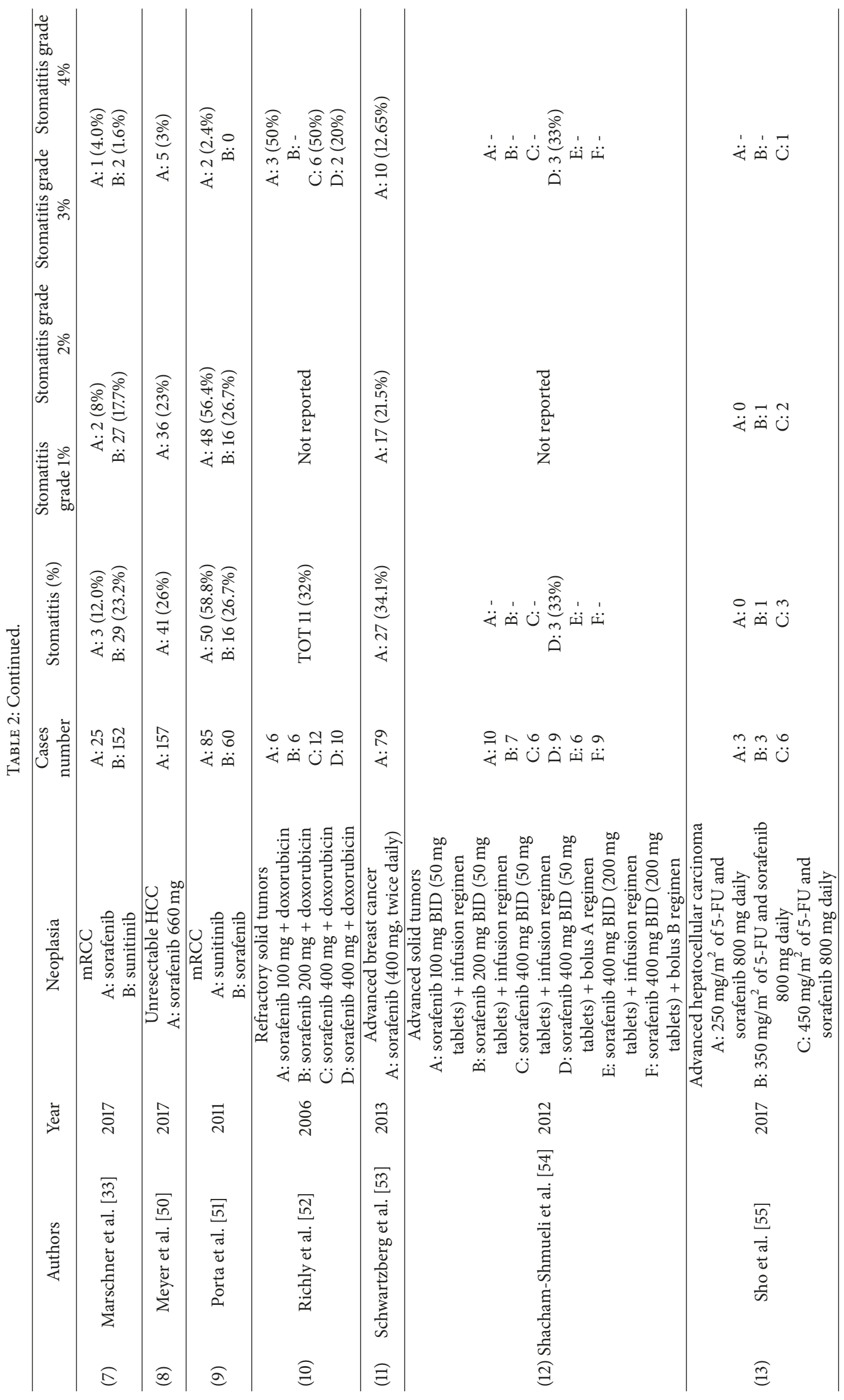




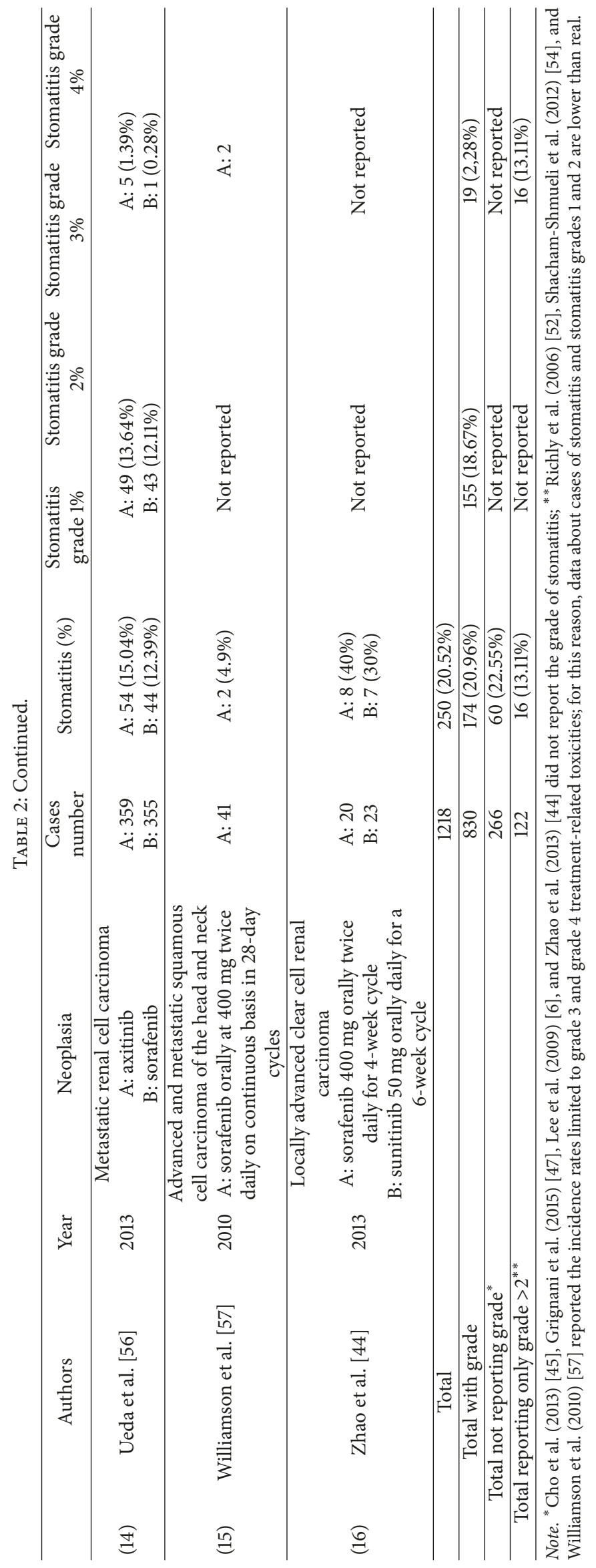




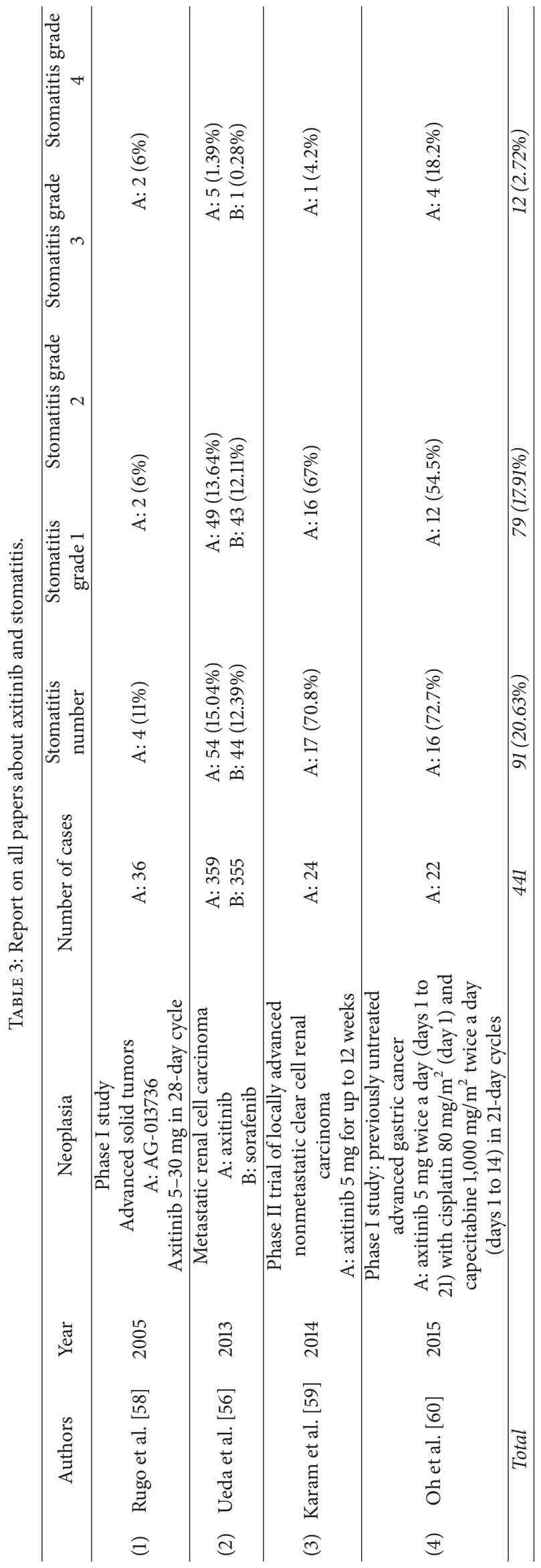


TABLE 4: Report on all papers about cabozantinib and stomatitis.

\begin{tabular}{|c|c|c|c|c|c|c|c|c|c|}
\hline & Authors & Year & Neoplasia & $\begin{array}{c}\text { nNumber of } \\
\text { cases }\end{array}$ & $\begin{array}{c}\text { Stomatitis } \\
\text { total }\end{array}$ & $\begin{array}{l}\text { Stomatitis } \\
\text { grade } 1\end{array}$ & $\begin{array}{l}\text { Stomatitis } \\
\text { grade } 2\end{array}$ & $\begin{array}{c}\text { Stomatitis } \\
\text { grade } 3\end{array}$ & $\begin{array}{c}\text { Stomatitis } \\
\text { grade } 4\end{array}$ \\
\hline 1 & $\begin{array}{c}\text { Neal et al. } \\
{[61]}\end{array}$ & 2016 & $\begin{array}{c}\text { Phase II trial for EGFR } \\
\text { wild-type } \\
\text { non-small-cell lung } \\
\text { cancer } \\
\text { A: erlotinib } \\
\text { B: cabozantinib } \\
\text { C: erlotinib + } \\
\text { cabozantinib }\end{array}$ & $\begin{array}{l}\text { A: } 40 \\
\text { B: } 40 \\
\text { C: } 39\end{array}$ & $\begin{array}{c}\text { A: } 2(5 \%) \\
\text { B: } 17(43 \%) \\
\text { C: } 9(24 \%)\end{array}$ & \multicolumn{2}{|c|}{$\begin{array}{c}\text { A: } 2(5 \%) \\
\text { B: } 13(33 \%) \\
\text { C: } 8(21 \%)\end{array}$} & $\begin{array}{c}\text { A: } 0 \\
\text { B: } 4(10 \%) \\
\text { C: } 1(3 \%)\end{array}$ & $\begin{array}{l}\text { A: } 0 \\
\text { B: } 0 \\
\text { C: } 0\end{array}$ \\
\hline 2 & $\begin{array}{c}\text { Tolaney et } \\
\text { al. [62] }\end{array}$ & 2017 & $\begin{array}{c}\text { Phase II metastatic } \\
\text { triple negative breast } \\
\text { cancer } \\
\text { A: oral dosing of } \\
\text { cabozantinib at } 60 \mathrm{mg} \\
\text { daily over a } 21 \text {-day cycle }\end{array}$ & A: 35 & A: 13 (37\%) & A: 11 & A: 2 & A: 0 & A: 0 \\
\hline & Total & & & 114 & 39 (34.21\%) & $34(2$ & $2 \%)$ & $5(4$ & $\%)$ \\
\hline
\end{tabular}

This method allows reaching a preferential localization of a drug in the region of disease, thus achieving an increase in local concentration. VEGFR TKI drugs work by inhibiting neoangiogenesis in the tumor.

The cloning of vascular endothelial growth factor in 1989 was a major step in understanding of tumor angiogenesis. Angiogenesis inhibitors are a class of drugs that include monoclonal antibodies and tyrosine kinase inhibitors.

In this review, we focused on oral side effects provoked by tyrosine kinase inhibitors. Small molecule inhibitors of VEGFR2 were first reported in 1996. This type of therapy is based on the fact that tumor cells can obtain the necessary oxygen and nutrients for survival by passive diffusion for tumor size $<1-2 \mathrm{~mm}$, but angiogenesis is necessary for tumor growth beyond the size of 100-300 cells [68]. The mRNAs for both VEGFR1 and VEGFR2 are reported to be upregulated in tumor-associated endothelial cells in comparison to the vasculature of the surrounding normal tissue. Moreover, recent studies highlighted that VEGF and VEGFR-1 and VEGFR-2 not only drive tumor angiogenesis but also directly stimulate tumor growth and the formation of metastases [69].

Overexpression of both VEGF and VEGFR is reported for many human solid cancers, including cancers of the gastrointestinal tract $[70,71]$, pancreas [72], breast $[73,74]$, stomach [75], cervix [76, 77], bladder [78, 79], kidney [78], prostate [80], ovaries [81, 82], endometrium [83], lung [84], brain $[85,86]$, and melanoma [87] and squamous cell carcinoma of the head and neck [88].

The main oral side effects reported in the studies include nonspecific stomatitis, dysgeusia, and xerostomia. These toxicities may occur alone or in combination.

Results of analysis of the literature showed that the incidence rate of overall stomatitis is higher in patients treated with sunitinib (40.08\%) compared to sorafenib $(22.55 \%)$, axitinib (20.63\%), and cabozantinib (34.21\%). Although it was not possible to carry out an accurate analysis of stomatitis by grade, it can be noted that most of the studies included in the review showed a high rate of minor stomatitis (G1-G2), while the onset of severe stomatitis (G3-G4) was lower. Indeed, in patients treated with sunitinib, the rate of incidence of low-grade stomatitis was $35.73 \%$, while the rate of incidence of high-grade stomatitis was $5.35 \%$; in patients treated with sorafenib, the rate of incidence of low-grade stomatitis was $18.67 \%$, while the rate of incidence of highgrade stomatitis was $2.28 \%$; in patients treated with axitinib, the rate of incidence of low-grade stomatitis was $17.91 \%$, while the incidence of high-grade stomatitis was $2.72 \%$; in patients treated with cabozantinib, the rate of incidence of low-grade stomatitis was $29.82 \%$, while the rate of incidence of high-grade stomatitis was $4.38 \%$. These results differ from those reported in literature about mucositis provoked by conventional chemotherapy in which mucositis is often a severe and dose-limiting toxicity.

The stomatitis caused by this kind of targeted therapy presents as a diffuse mucosal hypersensitivity/dysesthesia which can be associated with moderate erythema or inflammation of the oral mucosa. The symptoms appear in the first week of treatment and then gradually disappear [67, 89]. The literature reports that sunitinib and sorafenib may cause linear lingual ulcers of the nonkeratinized mucosa. Other typical oral side effects caused by treatment with VEGFR TKI are dysgeusia reported after treatment with cabozantinib and sunitinib and benign migratory glossitis which can be moderately painful and usually does not require any treatment modification or specific local treatment [90].

The changes in vascular permeability caused by the inhibition of VEGF can also induce mucocutaneous bleeding [91] and a delay in wound healing. Moreover, an oral screening for patients should be considered before undergoing therapy with antiangiogenic treatment. Treatment with tyrosine kinase inhibitors should end at least 1 week before oral surgery.

\section{Conclusion}

In conclusion, the targeted therapy has not kept the initial promises, as it determines several side effects, even if it is often lower than traditional chemotherapy. Regarding the 
oral cavity, the main side effect remains stomatitis, present in $20-30 \%$ of patients. The major advantage is that stomatitis is predominantly grade 1-2 in patients treated with targeted therapy while the effects of conventional chemotherapy are predominantly grades 3 and 4 .

\section{Conflicts of Interest}

The authors declare that there are no conflicts of interest regarding the publication of this paper.

\section{References}

[1] D. M. K. Keefe and E. H. Bateman, "Tumor control versus adverse events with targeted anticancer therapies," Nature Reviews Clinical Oncology, vol. 9, no. 2, pp. 98-109, 2012.

[2] J. B. Epstein, J. Thariat, R.-J. Bensadoun et al., "Oral complications of cancer and cancer therapy: from cancer treatment to survivorship," CA: A Cancer Journal for Clinicians, vol. 62, no. 6, pp. 400-422, 2012.

[3] W. Bensinger, M. Schubert, K. Ang, D. Brizel et al., "NCCN Task Force Report. prevention and management of mucositis in cancer care," Journal of the National Comprehensive Cancer Network, vol. 6, supplement 1, pp. S1-S21, 2008, quiz S22-S24.

[4] R. J. Motzer and R. M. Bukowski, "Targeted therapy for metastatic renal cell carcinoma," Journal of Clinical Oncology, vol. 24, no. 35, pp. 5601-5608, 2006.

[5] R. J. Motzer, S. Hoosen, C. L. Bello, and J. G. Christensen, "Sunitinib malate for the treatment of solid tumours: A review of current clinical data," Expert Opinion on Investigational Drugs, vol. 15, no. 5, pp. 553-561, 2006.

[6] W. J. Lee, J. L. Lee, S. E. Chang et al., "Cutaneous adverse effects in patients treated with the multitargeted kinase inhibitors sorafenib and sunitinib," British Journal of Dermatology, vol. 161, no. 5, pp. 1045-1051, 2009.

[7] J. Dengjel, I. Kratchmarova, and B. Blagoev, "Receptor tyrosine kinase signaling: A view from quantitative proteomics," Molecular BioSystems, vol. 5, no. 10, pp. 1112-1121, 2009.

[8] R. J. Motzer, T. E. Hutson, P. Tomczak et al., "Sunitinib versus interferon alfa in metastatic renal-cell carcinoma," The New England Journal of Medicine, vol. 356, pp. 115-124, 2007.

[9] G. Sonpavde and T. E. Hutson, "Pazopanib: A novel multitargeted tyrosine kinase inhibitor," Current Oncology Reports, vol. 9, no. 2, pp. 115-119, 2007.

[10] S. Faivre, C. Delbaldo, K. Vera et al., "Safety, pharmacokinetic, and antitumor activity of SU11248, a novel oral multitarget tyrosine kinase inhibitor, in patients with cancer," Journal of Clinical Oncology, vol. 24, no. 1, pp. 25-35, 2006.

[11] R. M. Bukowski, "Third generation tyrosine kinase inhibitors and their development in advanced renal cell carcinoma," Frontiers in Oncology, vol. 2, Article ID 00013, 2012.

[12] B. Escudier, T. Eisen, W. M. Stadler, C. Szczylik et al., "Sorafenib for treatment of renal cell carcinoma: final efficacy and safety results of the phase III treatment approaches in renal cancer global evaluation trial," Journal of Clinical Oncology, vol. 27, no. 20, pp. 3312-3318, 2009.

[13] A. M. Pick and K. K. Nystrom, "Pazopanib for the treatment of metastatic renal cell carcinoma," Clinical Therapeutics, vol. 34, no. 3, pp. 511-520, 2012.
[14] G. D. Demetri, "Differential properties of current tyrosine kinase inhibitors in gastrointestinal stromal tumors," Seminars in Oncology, vol. 38, no. 1, pp. S10-S19, 2011.

[15] D. C. Smith, M. R. Smith, and C. Sweeney, "Cabozantinib in patients with advanced prostate cancer: results of a phase II randomized discontinuation trial," Journal of Clinical Oncology, vol. 31, no. 4, pp. 412-419, 2013.

[16] U. Vaishampayan, "Cabozantinib as a novel therapy for renal cell carcinoma," Current Oncology Reports, vol. 15, no. 2, pp. 7682, 2013.

[17] K. Traynor, "Cabozantinib approved for advanced medullary thyroid cancer," American Journal of Health-System Pharmacy, vol. 70, no. 2, p. 88, 2013.

[18] M. Arakawa-Todo, T. Yoshizawa, K. Zennami, G. Nishikawa et al., "Management of adverse events in patients with metastatic renal cell carcinoma treated with sunitinib and clinical outcomes," Anticancer Research, vol. 33, no. 11, pp. 5043-5050, 2013.

[19] A. J. Armstrong, S. Halabi, T. Eisen et al., "Everolimus versus sunitinib for patients with metastatic non-clear cell renal cell carcinoma (ASPEN): A multicentre, open-label, randomised phase 2 trial," The Lancet Oncology, vol. 17, no. 3, pp. 378-388, 2016.

[20] Y.-J. Bang, Y.-K. Kang, W. K. Kang et al., "Phase II study of sunitinib as second-line treatment for advanced gastric cancer," Investigational New Drugs, vol. 29, no. 6, pp. 1449-1458, 2011.

[21] F. Cardoso, J.-L. Canon, D. Amadori et al., "An exploratory study of sunitinib in combination with docetaxel and trastuzumab as first-line therapy for HER2-positive metastatic breast cancer," The Breast, vol. 21, no. 6, pp. 716-723, 2012.

[22] A. Carrato, A. Swieboda-Sadlej, M. Staszewska-Skurczynska et al., "Fluorouracil, leucovorin, and irinotecan plus either sunitinib or placebo in metastatic colorectal cancer: A randomized, phase III trial," Journal of Clinical Oncology, vol. 31, no. 10, pp. 1341-1347, 2013.

[23] A. Dirican, Y. Kucukzeybek, C. Erten et al., "Prognostic and predictive value of hematologic parameters in patients with metastatic renal cell carcinoma: Second line sunitinib treatment following IFN-alpha," Asian Pacific Journal of Cancer Prevention, vol. 14, no. 3, pp. 2101-2105, 2013.

[24] M. Domagala-Haduch, I. Cedrych, M. Jasiówka, M. Niemiec, and P. Skotnicki, "Analysis of adverse events of sunitinib in patients treated for advanced renal cell carcinoma," Archives of Medical Science, vol. 12, no. 2, pp. 360-364, 2016.

[25] V. L. Goodman, E. P. Rock, R. Dagher et al., "Approval summary: Sunitinib for the treatment of imatinib refractory or intolerant gastrointestinal stromal tumors and advanced renal cell carcinoma," Clinical Cancer Research, vol. 13, no. 5, pp. 13671373, 2007.

[26] V. Grünwald, I. M. E. Desar, J. Haanen et al., "A Phase I study of recombinant human interleukin-21 (rIL-21) in combination with sunitinib in patients with metastatic renal cell carcinoma (RCC)," Acta Oncologica, vol. 50, no. 1, pp. 121-126, 2011.

[27] M. H. Hong, H. S. Kim, C. Kim et al., "Treatment outcomes of sunitinib treatment in advanced renal cell carcinoma patients: a single cancer center experience in Korea," Cancer Research and Treatment, vol. 41, no. 2, pp. 67-72, 2009.

[28] P. H. O’Donnell, "Efficacy and toxicity of sunitinib in patients with metastatic renal cell carcinoma with severe renal impairment or on haemodialysis," BJU International, vol. 108, no. 8, pp. 1284-1285, 2011.

[29] K. H. Kim, H. Y. Kim, H. R. Kim et al., "Efficacy and toxicity of sunitinib in patients with metastatic renal cell carcinoma with 
renal insufficiency," European Journal of Cancer, vol. 50, no. 4, pp. 746-752, 2014.

[30] J. H. Lee, S.-G. Chang, S. H. Jeon, G. E. Min, and K. H. Yoo, "Comparative analysis between immunochemotherapy and target therapy for metastatic renal cell carcinoma: Overview of treatment-related adverse events and the dropout rate in Korea," Korean Journal of Urology, vol. 51, no. 6, pp. 379-385, 2010.

[31] J. L. Lee, M. K. Kim, I. Park et al., "RandomizEd phase II trial of Sunitinib four weeks on and two weeks off versus Two weeks on and One week off in metastatic clear-cell type REnal cell carcinoma: RESTORE trial," Annals of Oncology, vol. 26, no. 11, Article ID mdv357, pp. 2300-2305, 2015.

[32] K.-W. Lee, S. R. Park, D.-Y. Oh et al., "Phase I study of sunitinib plus capecitabine/cisplatin or capecitabine/oxaliplatin in advanced gastric cancer," Investigational New Drugs, vol. 31, no. 6, pp. 1547-1558, 2013.

[33] N. Marschner, L. Müller, A. Münch, K. Blumenstengel, U. Hutzschenreuter, and S. Busies, "Adverse reactions in mRCC patients documented in routine practice by German officebased oncologists and uro-oncologists," Journal of Oncology Pharmacy Practice, vol. 23, no. 4, pp. 288-295, 2017.

[34] M. H. Mir, K. H. Changal, S. A. Aziz, G. M. Bhat, and A. R. Lone, "Sunitinib in metastatic renal cell carcinoma (mRCC): a developing country experience. Do our patients behave differently than the Western patients?" International Urology and Nephrology, vol. 48, no. 11, pp. 1811-1816, 2016.

[35] P. H. Patel, P. L. Senico, R. E. Curiel, and R. J. Motzer, "Phase I study combining treatment with temsirolimus and sunitinib malate in patients with advanced renal cell carcinoma," Clinical Genitourinary Cancer, vol. 7, no. 1, pp. 24-27, 2009.

[36] C. Porta, S. Osanto, A. Ravaud et al., "Management of adverse events associated with the use of everolimus in patients with advanced renal cell carcinoma," European Journal of Cancer, vol. 47, no. 9, pp. 1287-1298, 2011.

[37] E. P. Rock, V. Goodman, J. X. Jiang et al., "Food and Drug Administration drug approval summary: sunitinib malate for the treatment of gastrointestinal stromal tumor and advanced renal cell carcinoma," The Oncologist, vol. 12, no. 1, pp. 107-113, 2007.

[38] M. A. Socinski, S. Novello, J. R. Brahmer et al., "Multicenter, phase II trial of sunitinib in previously treated, advanced nonsmall-cell lung cancer," Journal of Clinical Oncology, vol. 26, no. 4, pp. 650-656, 2008.

[39] G. Sonpavde, P. O. Periman, D. Bernold et al., "Sunitinib malate for metastatic castration-resistant: Prostate cancer following docetaxel-based: Chemotherapy," Annals of Oncology, vol. 21, no. 2, pp. 319-324, 2010.

[40] C. N. Sternberg, F. Calabrò, S. Bracarda et al., "Safety and efficacy of sunitinib in patients from Italy with metastatic renal cell carcinoma: Final results from an expanded-access trial," Oncology, vol. 88, no. 5, pp. 273-280, 2015.

[41] A. A. M. Van Der Veldt, E. Boven, H. H. Helgason et al., "Predictive factors for severe toxicity of sunitinib in unselected patients with advanced renal cell cancer," British Journal of Cancer, vol. 99, no. 2, pp. 259-265, 2008.

[42] I. Yildiz, F. Sen, M. Basaran et al., "Response rates and adverse effects of continuous once-daily sunitinib in patients with advanced renal cell carcinoma: A single-center study in Turkey," Japanese Journal of Clinical Oncology, vol. 41, no. 12, Article ID hyr151, pp. 1380-1387, 2011.
[43] C. Yoo, J. E. Kim, J.-L. Lee et al., "The efficacy and safety of sunitinib in Korean patients with advanced renal cell carcinoma: High incidence of toxicity leads to frequent dose reduction," Japanese Journal of Clinical Oncology, vol. 40, no. 10, Article ID hyq073, pp. 980-985, 2010.

[44] J. Zhao, Y. Zhu, C. Zhang et al., "Sorafenib or sunitinib as postoperative adjuvant therapy for Chinese patients with locally advanced clear cell renal cell carcinoma at high risk for disease recurrence," Urologic Oncology: Seminars and Original Investigations, vol. 31, no. 8, pp. 1800-1805, 2013.

[45] J.-Y. Cho, Y.-H. Paik, H. Y. Lim et al., "Clinical parameters predictive of outcomes in sorafenib-treated patients with advanced hepatocellular carcinoma," Liver International, vol. 33, no. 6, pp. 950-957, 2013.

[46] A. Chrisoulidou, S. Mandanas, E. Margaritidou et al., "Treatment compliance and severe adverse events limit the use of tyrosine kinase inhibitors in refractory thyroid cancer," OncoTargets and Therapy, vol. 8, pp. 2435-2442, 2015.

[47] G. Grignani, E. Palmerini, V. Ferraresi et al., "Sorafenib and everolimus for patients with unresectable high-grade osteosarcoma progressing after standard treatment: a non-randomised phase 2 clinical trial," The Lancet Oncology, vol. 16, no. 1, pp. 98107, 2015.

[48] J. D. Hainsworth, D. S. Thompson, J. A. Bismayer et al., "Paclitaxel/carboplatin with or without sorafenib in the firstline treatment of patients with stage III/IV epithelial ovarian cancer: A randomized phase II study of the Sarah Cannon Research Institute," Cancer Medicine, vol. 4, no. 5, pp. 673-681, 2015.

[49] J. D. Hainsworth, D. M. Waterhouse, W. C. Penley et al., "Sorafenib and everolimus in advanced clear cell renal carcinoma: A phase I/II trial of the SCRI oncology research consortium," Cancer Investigation, vol. 31, no. 5, pp. 323-329, 2013.

[50] T. Meyer, R. Fox, Y. Ma, P. Ross et al., "Sorafenib in combination with transarterial chemoembolisation in patients with unresectable hepatocellular carcinoma (TACE 2): a randomised placebo-controlled, double-blind, phase 3 trial," The Lancet Gastroenterology and Hepatology, vol. 2, no. 8, pp. 565-575, 2017.

[51] C. Porta, C. Paglino, I. Imarisio et al., "Safety and treatment patterns of multikinase inhibitors in patients with metastatic renal cell carcinoma at a tertiary oncology center in Italy," BMC Cancer, vol. 11, article 105, 2011.

[52] H. Richly, B. F. Henning, P. Kupsch et al., "Results of a Phase I trial of sorafenib (BAY 43-9006) in combination with doxorubicin in patients with refractory solid tumors," Annals of Oncology, vol. 17, no. 5, pp. 866-873, 2006.

[53] L. S. Schwartzberg, K. W. Tauer, R. C. Hermann et al., "Sorafenib or placebo with either gemcitabine or capecitabine in patients with HER-2-negative advanced breast cancer that progressed during or after bevacizumab," Clinical Cancer Research, vol. 19, no. 10, pp. 2745-2754, 2013.

[54] E. Shacham-Shmueli, R. Geva, A. Figer et al., "Phase I trial of sorafenib in combination with 5-fluorouracil/leucovorin in advanced solid tumors," Clinical Pharmacology and Therapeutics, vol. 52, no. 5, pp. 656-669, 2012.

[55] T. Sho, M. Nakanishi, K. Morikawa et al., "A phase I study of combination therapy with sorafenib and 5-fluorouracil in patients with advanced hepatocellular carcinoma," Drugs in R\&D, vol. 17, no. 3, pp. 381-388, 2017.

[56] T. Ueda, H. Uemura, Y. Tomita et al., "Efficacy and safety of axitinib versus sorafenib in metastatic renal cell carcinoma: 
Subgroup analysis of Japanese patients from the global randomized phase 3 AXIS trial," Japanese Journal of Clinical Oncology, vol. 43, no. 6, Article ID hyt054, pp. 616-628, 2013.

[57] S. K. Williamson, J. Moon, C. H. Huang et al., "Phase II evaluation of sorafenib in advanced and metastatic squamous cell carcinoma of the head and neck: southwest oncology group study S0420," Journal of Clinical Oncology, vol. 28, no. 20, pp. 3330-3335, 2010.

[58] H. S. Rugo, R. S. Herbst, G. Liu et al., "Phase I trial of the oral antiangiogenesis agent AG-013736 in patients with advanced solid tumors: Pharmacokinetic and clinical results," Journal of Clinical Oncology, vol. 23, no. 24, pp. 5474-5483, 2005.

[59] J. A. Karam, C. E. Devine, D. L. Urbauer et al., "Phase 2 trial of neoadjuvant axitinib in patients with locally advanced nonmetastatic clear cell renal cell carcinoma," European Urology, vol. 66, no. 5, pp. 874-880, 2014.

[60] D.-Y. Oh, T. Doi, K. Shirao et al., "Phase I study of axitinib in combination with cisplatin and capecitabine in patients with previously untreated advanced gastric cancer," Cancer Research and Treatment, vol. 47, no. 4, pp. 687-696, 2015.

[61] J. W. Neal, S. E. Dahlberg, H. A. Wakelee et al., "Erlotinib, cabozantinib, or erlotinib plus cabozantinib as second-line or third-line treatment of patients with EGFR wild-type advanced non-small-cell lung cancer (ECOG-ACRIN 1512): a randomised, controlled, open-label, multicentre, phase 2 trial," The Lancet Oncology, vol. 17, no. 12, pp. 1661-1671, 2016.

[62] S. M. Tolaney, D. R. Ziehr, H. Guo et al., "Phase II and biomarker study of cabozantinib in metastatic triple-negative breast cancer patients," The Oncologist, vol. 22, no. 1, pp. 25-32, 2017.

[63] N. Bhojani, C. Jeldres, J.-J. Patard et al., "Toxicities associated with the administration of sorafenib, sunitinib, and temsirolimus and their management in patients with metastatic renal cell carcinoma," European Urology, vol. 53, no. 5, pp. 917930, 2008.

[64] J. Desai, L. Yassa, E. Marqusee et al., "Hypothyroidism after sunitinib treatment for patients with gastrointestinal stromal tumors," Annals of Internal Medicine, vol. 145, no. 9, pp. 660664, 2006.

[65] P. Suwattee, S. Chow, B. C. Berg, and E. M. Warshaw, "Sunitinib: a cause of bullous palmoplantar erythrodysesthesia, periungual erythema, and mucositis," JAMA Dermatology, vol. 144, no. 1, pp. 123-125, 2008.

[66] M. E. Lacouture, L. M. Reilly, P. Gerami, and J. Guitart, "Hand foot skin reaction in cancer patients treated with the multikinase inhibitors sorafenib and sunitinib," Annals of Oncology, vol. 19, no. 11, pp. 1955-1961, 2008.

[67] A. Yuan, S. L. Kurtz, C. M. Barysauskas, A. P. Pilotte, A. J. Wagner, and N. S. Treister, "Oral adverse events in cancer patients treated with VEGFR-directed multitargeted tyrosine kinase inhibitors," Oral Oncology, vol. 51, no. 11, pp. 1026-1033, 2015.

[68] R. S. Kerbel, "Tumor angiogenesis: past, present and the near future," Carcinogenesis, vol. 21, no. 3, pp. 505-515, 2000.

[69] P. W. Manley, G. Martiny-Baron, J.-M. Schlaeppi, and J. M. Wood, "Therapies directed at vascular endothelial growth factor," Expert Opinion on Investigational Drugs, vol. 11, no. 12, pp. 1715-1736, 2002.

[70] L. F. Brown, B. Berse, R. W. Jackman et al., "Expression of vascular permeability factor (vascular endothelial growth factor) and its receptors in adenocarcinomas of the gastrointestinal tract," Cancer Research, vol. 53, no. 19, pp. 4727-4735, 1993.
[71] G. Lindmark, B. Gerdin, C. Sundberg, L. Påhlman, R. Bergström, and B. Glimelius, "Prognostic significance of the microvascular count in colorectal cancer," Journal of Clinical Oncology, vol. 14, no. 2, pp. 461-466, 1996.

[72] J. Itakura, T. Ishiwata, B. Shen, M. Kornmann, and M. Korc, "Concomitant over-expression of vascular endothelial growth factor and its receptors in pancreatic cancer," International Journal of Cancer, vol. 85, no. 1, pp. 27-34, 2000.

[73] L. F. Brown, B. Berse, R. W. Jackman et al., "Expression of vascular permeability factor (vascular endothelial growth factor) and its receptors in breast cancer," Human Pathology, vol. 26, no. 1, pp. 86-91, 1995.

[74] N. Weidner, J. P. Semple, W. R. Welch, and J. Folkman, “Tumor angiogenesis and metastasis-correlation in invasive breast carcinoma," The New England Journal of Medicine, vol. 324, no. 1, pp. 1-8, 1991.

[75] N. Tanigawa, H. Amaya, M. Matsumura, T. Shimomatsuya et al., "Extent of tumor vascularization correlates with prognosis and hematogenous metastasis in gastric carcinomas," Cancer Research, vol. 56, no. 11, pp. 2671-2676, 1996.

[76] A. J. Guidi, G. Abu-Jawdeh, B. Berse et al., "Vascular permeability factor (vascular endothelial growth factor) expression and angiogenesis in cervical neoplasia," Journal of the National Cancer Institute, vol. 87, no. 16, pp. 1237-1245, 1995.

[77] F. Sillman, J. Boyce, and R. Fruchter, "The significance of atypical vessels and neovascularization in cervical neoplasia," American Journal of Obstetrics \& Gynecology, vol. 139, no. 2, pp. 154-159, 1981.

[78] L. F. Brown, B. Berse, R. W. Jackman, and K. Tognazzi, "Increased expression of vascular permeability factor (vascular endothelial growth factor) and its receptors in kidney and bladder carcinomas," American Journal of Pathology, vol. 143, no. 5, pp. 1255-1262, 1993.

[79] B. H. Bochner, R. J. Cote, N. Weidner et al., "Angiogenesis in bladder cancer: Relationship between microvessel density and tumor prognosis," Journal of the National Cancer Institute, vol. 87, no. 21, pp. 1603-1612, 1995.

[80] S. A. Bigler, R. E. Deering, and M. K. Brawer, "Comparison of microscopic vascularity in benign and malignant prostate tissue," Human Pathology, vol. 24, no. 2, pp. 220-226, 1993.

[81] T. A. Olson, D. Mohanraj, L. F. Carson, and S. Ramakrishnan, "Vascular permeability factor gene expression in normal and neoplastic human ovaries," Cancer Research, vol. 54, no. 1, pp. 276-280, 1994.

[82] G. Gasparini, E. Bonoldi, G. Viale et al., "Prognostic and predictive value of tumour angiogenesis in ovarian carcinomas," International Journal of Cancer, vol. 69, no. 3, pp. 205-211, 1996.

[83] A. J. Guidi, G. Abu-Jawdeh, K. Tognazzi, H. F. Dvorak, and L. F. Brown, "Expression of vascular permeability factor (vascular endothelial growth factor) and its receptors in endometrial carcinoma," Cancer, vol. 78, no. 3, pp. 454-460, 1996.

[84] P. Macchiarini, G. Fontanini, F. Squartini, C. A. Angeletti, and M. J. Hardin, "Relation of neovascularisation to metastasis of non-small-cell lung cancer," The Lancet, vol. 340, no. 8812, pp. 145-146, 1992.

[85] K. H. Plate, G. Breier, H. A. Weich, and W. Risau, "Vascular endothelial growth factor is a potential tumour angiogenssis factor in human gliomas in vivo," Nature, vol. 359, no. 6398, pp. 845-848, 1992.

[86] V. W. Li, C. Yu AB, J. Folkman et al., "Microvessel count and cerebrospinal fluid basic fibroblast growth factor in children 
with brain tumours," The Lancet, vol. 344, no. 8915, pp. 82-86, 1994.

[87] R. L. Barnhill, K. Fandrey, M. A. Levy, M. C. Mihm Jr., and B. Hyman, "Angiogenesis and tumor progression of melanoma: Quantification of vascularity in melanocytic nevi and cutaneous malignant melanoma," Laboratory Investigation, vol. 67, no. 3, pp. 331-337, 1992.

[88] G. Gasparini, N. Weidner, S. Maluta et al., "Intratumoral microvessel density and L53 protein: Correlation with metastasis in head-and-neck squamous-cell carcinoma," International Journal of Cancer, vol. 55, no. 5, pp. 739-744, 1993.

[89] V. Sibaud, F. Boralevi, E. Vigarios, and J.-C. Fricain, "Oral toxicity of targeted anticancer therapies," Annales de Dermatologie et de Venereologie, vol. 141, no. 5, pp. 354-363, 2014.

[90] E. Vigarios, J. B. Epstein, and V. Sibaud, "Oral mucosal changes induced by anticancer targeted therapies and immune checkpoint inhibitors," Supportive Care in Cancer, vol. 25, no. 5, pp. 1713-1739, 2017.

[91] L. Thomas, S. Y. Lai, W. Dong et al., "Sorafenib in metastatic thyroid cancer: a systematic review," The Oncologist, vol. 19, no. 3, pp. 251-258, 2014. 

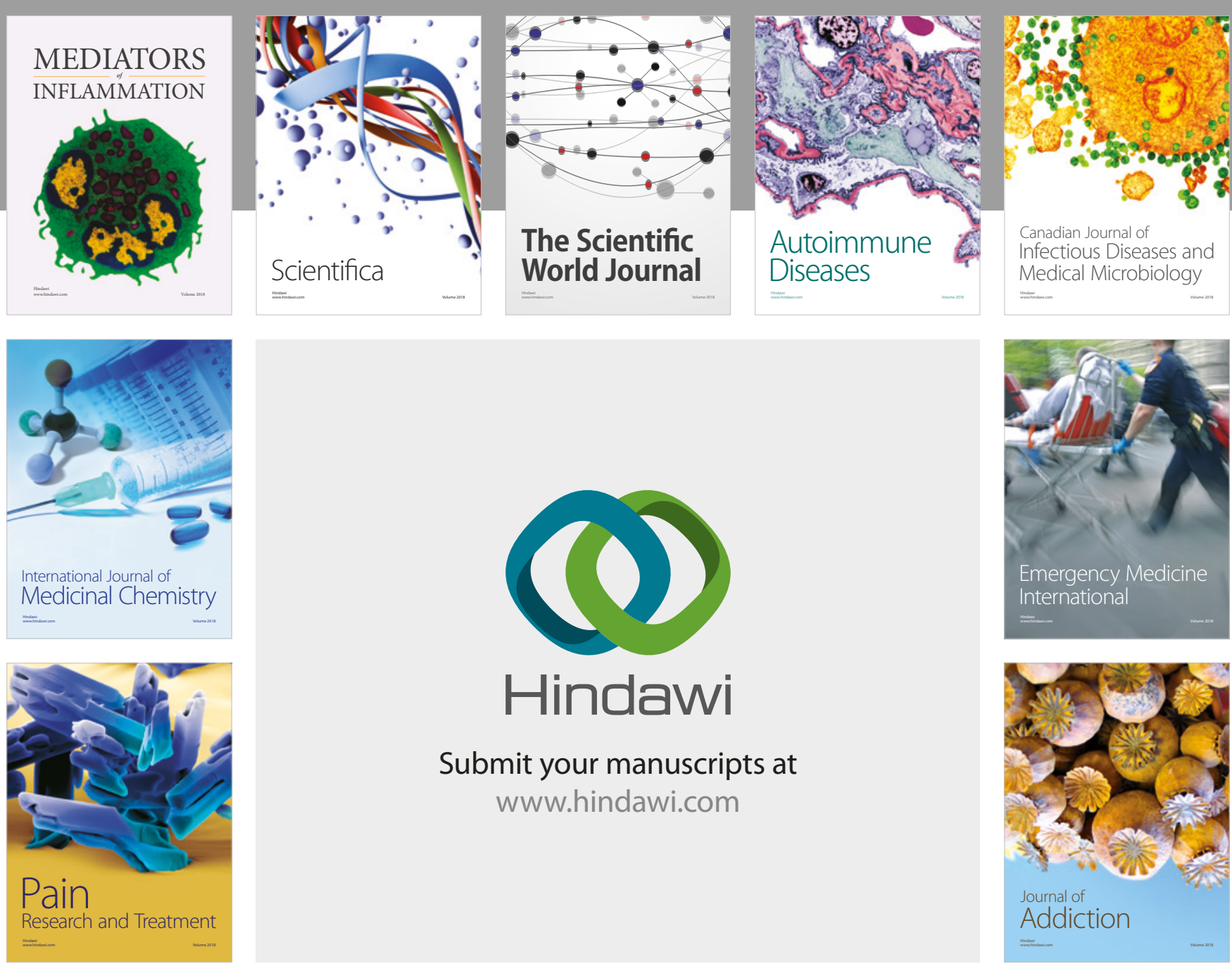

Canadian Journal of
Infectious Diseases and Medical Microbiology

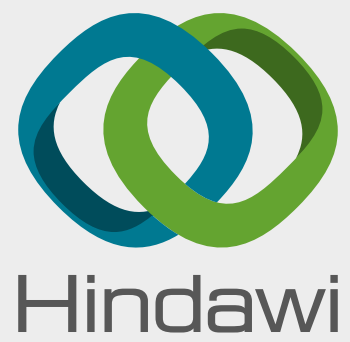

Submit your manuscripts at

www.hindawi.com
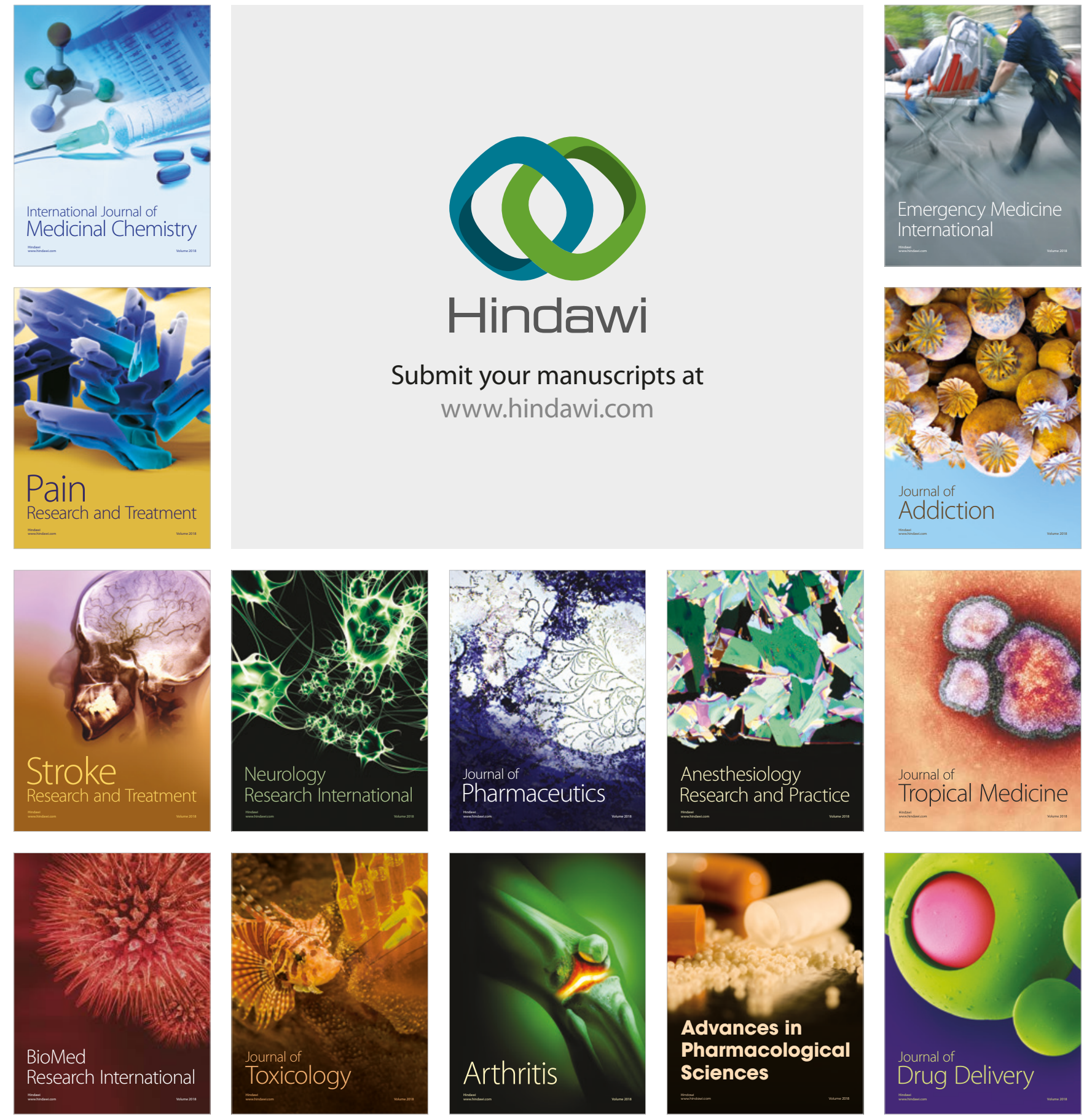